\title{
Hepatoprotective Effect of Yellow and Red Carrots (Daucus carota L.) Against Carbon Tetrachloride-Induced Hepatotoxicity
}

\author{
Mohamed K. Abo-Golayel ${ }^{1,2 *}$ and Wafik A. Al-Khayat ${ }^{3}$ \\ ${ }^{1}$ Medical Research Center, Ain Shams University Hospitals, Ain Shams University, Cairo, Egypt, \\ ${ }^{2}$ Biochemistry Department, Faculty of Science, King Abdulaziz University, Kingdom of Saudi Arabia (KSA), \\ ${ }^{3}$ Toxicology Center, Ain Shams University Hospitals, Ain Shams University, Cairo, Egypt
}

\section{A R T I C L E I N F O}

Article history:

Received 02 June 2014

Accepted 14 July 2014

Keywords:

Liver damage;

Daucus carota L.;

hepatoprotection;

carbon tetrachloride.

\begin{abstract}
A B S T R A C T
Plant products play a crucial role in the hepatoprotection through its antioxidants property. Therefore, this study was designed to focus on the efficacy of the hepatoprotective activity of yellow and red carrots water extracts against carbon tetrachloride hepatic-intoxication in rats. Rats were randomly divided into two groups; group-A (normal control) and group-B (liver injured group). Assessment of various serum enzymatic activities of alanine transaminase, aspartate transaminase, gamma glutamyl transferase, lactate dehydrogenase and Acetyl choline esterase as well as albumin and urea concentrations, liver histopathology and genomic DNA integrity. The present data revealed significant elevation in the serum liver enzymes, DNA damage and histopatological alterations in $\mathrm{CCl}_{4}$ treated rats particularly by the end of the study indicating severe hepatic damage, which were improved and almost reversed with obvious repair in genomic DNA integrity via administration of red or yellow carrot extracts. The present study demonstrated that both red and yellow carrot extracts could afford significant protection against hepatocellular injury with more potential hepatoprotection in case of red carrot administration.
\end{abstract}

\section{Introduction}

Medicinal plants are extremely valuable all over the world as a prosperous bioactive source for the prevention and treatment of ailments. Herbal medicines are being used by about $80 \%$ of the world population particularly in the developing countries for primary health care. They have stood the test of time for their safety, efficacy, cultural acceptability and minimal side effects. The incredible complexity of liver chemistry and its fundamental role in human physiology is so daunting to researchers that they visualize that perhaps simple plant remedies could have something to offer is astonishing and incredible ${ }^{[1]}$.

Medicinal herbs are significant source of hepatoprotective drugs, some of which have the property to prevent and treat hepatic disturbances with interception of minimum side effects. Hepatoprotectives are a class of therapeutic agents which offer protection to liver from damage and help in regeneration of hepatic cells ${ }^{[2]}$.

\footnotetext{
* Corresponding author.

E-mail address: mohdabogolayel2006@yahoo.com
}

Carbon tetrachloride $\left(\mathrm{CCl}_{4}\right)$ is a selective hepatotoxic chemical agent, $\mathrm{CCl}_{4}$-induced reactive free radicals initiate cell damage through two different mechanisms of covalent binding to the membrane proteins and cause lipid peroxidation ${ }^{[3]}$. This causes severe damage to cell membranes and alters the enzymatic activity, with subsequent induction of hepatic injury or necrosis ${ }^{[4]}$. Its metabolic transformation to highly toxic trichloromethyl $\left(\mathrm{CCl}_{3}\right)$ and trichloromethyl peroxyl $\left(\mathrm{CCl}_{3} \mathrm{O}_{2}\right)$ free radicals by cytochrome $\mathrm{P} 450$ enzyme causes cellular damage ${ }^{[5]}$.

So, investigations into the natural material that could produce better therapeutic effect became a persisting need to overcome the pharmaceutical imbalance between remedies which protect the liver and drugs that induce hepatotoxicity ${ }^{[6]}$. Daucus carota commonly known as "Carrot" is one of the most important vegetables and belongs to the family of Apiaceae. Its active ingredients like volatile oils, steroids, tannins, flavonoids, and carotene have been isolated ${ }^{[7]}$. Carrot seeds are rich of antioxidants ${ }^{[8]}$. On the other hand, carrot contains carotenoids which are natural pigments with lipophilic properties and antioxidant characteristic. The major car- 
otenoids in human plasma are $\beta$-Carotene and lycopene. They are transported in blood complexes to plasma lipoproteins, mainly to the LDL particle that supplements with $\beta$-carotene or with lycopene leads to an increased resistance to oxidation ${ }^{[9]}$. Concerning health benefits, carrots are an excellent source of several antioxidant compounds such as phenolic compounds that play an important role in antioxidant properties of carrots and the other hydroxycinnamic derivatives such as dicaffeoylquinic acids in the extracts may exert some strong antioxidant activities along with chlorogenic acid ${ }^{[10]}$. Experimental and clinical studies on carrots (powder or extract) and its active constituents (mainly carotenoids) revealed that they have hyperglycemic effect ${ }^{[11]}$, anticancer activity due to the presence of alpha carotene and falcarinol ${ }^{[12]}$, protective effect against coronary heart disease, hypocholesterolemic and hypolipidemic activities ${ }^{[13]}$.

The present study therefore, focused on the probable potential hepatoprotective efficacy of red and yellow carrots water extracts supplementation against $\mathrm{CCl}_{4^{-}}$ induced hepatic injury to the livers of male albino rats.

\section{Materials and Methods}

\section{Preparation of carrot water extracts for rats:}

Fresh roots of Daucus carota L. commonly known as carrot, belong to the family of Apiaceae (red, yellow) were purchased from local market. Two hundred g. of carrots were homogenized (without adding water) and squeezed through cheesecloth to obtain the extract (juice). Freshly prepared extracts were orally administered daily at a dose of $25 \mathrm{ml} / \mathrm{kg}$ body weight, using intra-gastric catheter tube to ensure the secure and proper ingestion of the extract in accordance with the method described by Dawit et al. ${ }^{[14]}$.

\section{Induction of liver fibrosis in rats and experimental design:}

One hundred and fourteen male Wister albino rats weighing 150-200 $\mathrm{g}$ were used as the experimental animal model. Animals were housed in well-ventilated polypropylene cages with husk beds. Rats were acclimatized to conditions in the laboratory $\left(26-28{ }^{\circ} \mathrm{C}\right.$, $60-80 \%$ relative humidity, $12 \mathrm{~h}$ light/dark cycle) for 10 days before the experimental running, during which they received standard diet and tap water ad libitum ${ }^{[15]}$. Rats were subcutaneously injected at a dose of $0.2 \mathrm{ml} / 100 \mathrm{~g}$ body weight of $40 \mathrm{ml} / \mathrm{L} \mathrm{CCl}_{4}$ dissolved in paraffin oil starting from day one of the experiment ${ }^{[16]}$. Ethical clearance was obtained from Institutional Animal Ethical Committee of Ain-Shams University.

Route of administration: Red and yellow carrot extracts were orally administered using intra-gastric catheter tube to ensure the secure and proper ingestion of the extract in accordance with the method recommended by Dawit et al. ${ }^{[14]}$ and Al-Malki et al. ${ }^{[15]}$. Rats were randomly divided into two main groups. Group-A (normal control group) and group-B (liver injured group).
Group-A: This group included twenty-four rats, which were left to serve as normal basic control.

Group-B: This group included ninety rats, which were all injected subcutaneously with previously prepared $\mathrm{CCl}_{4}$ twice a week starting from day one of the experiment till the end of the experiment ${ }^{[15,16]}$. Group$\mathrm{B}$ was divided as follows:

Group $-\mathrm{B}_{1}$ : This group included thirty rats that served as a control pollutant group (+ve control) and were subdivided into five subgroups $\left(\mathrm{B}_{1}-1, \mathrm{~B}_{1}-2, \mathrm{~B}_{1}-3, \mathrm{~B}_{1}-4\right.$ $\& \mathrm{~B}_{1}-5$ ); each subgroup included six rats.

Group- $\mathrm{B}_{2}$ : This group included thirty rats, which were introduced with $25 \mathrm{ml} / \mathrm{kg}$ body weight red carrot extract once/day. This group was subdivided into five subgroups $\left(\mathrm{B}_{2}-1, \mathrm{~B}_{2}-2, \mathrm{~B}_{2}-3, \mathrm{~B}_{2}-4 \quad \& \quad \mathrm{~B}_{2}-5\right)$; each subgroup included six rats.

Group- $B_{3}$ : This group included thirty rats, which were introduced with $25 \mathrm{ml} / \mathrm{kg}$ body weight yellow carrot extracts once/day. This group was subdivided into five subgroups $\left(\mathrm{B}_{3}-1, \mathrm{~B}_{3}-2, \mathrm{~B}_{3}-3, \mathrm{~B}_{3}-4\right.$ \& $\left.\mathrm{B}_{3}-5\right)$; each subgroup included six rats.

Six rats of each group; $B_{1}, B_{2}$ and $B_{3}$ were sacrificed at the end of the $1^{\text {st }}, 2^{\text {nd }} 3^{\text {th }}, 4^{\text {th }}$ and $5^{\text {th }}$ weeks of the study.

\section{Samples collection and biochemical assays}

Blood sample from each rat was collected in a centrifuge tube and kept at room temperature for 20 minutes. Serum of each studied rat was separated by centrifugation at $3000 \mathrm{rpm}$ for 10 minutes using a cooling centrifuge (Beckman, CS-15R Centrifuge, California-USA). Serum samples were used for determination of the enzymatic activities of alanine transaminase (ALT) ${ }^{[17]}$, aspartate transaminase (AST) ${ }^{[17]}$, gamma glutamyl transferase (GGT) ${ }^{[18]}$, lactate dehydrogenase (LDH) ${ }^{[19]}$ and acetylcholinesterase (AChE) concentration ${ }^{[20]}$ as well as urea ${ }^{[21]}$, albumin ${ }^{[22]}$ concentrations (Bio-Med, Egy-Chem, Egypt). The abdomen of each rat was excised immediately after scarifying and the liver was excised and divided into two portions, one portion was immersed immediately into $10 \%$ buffered neutral formaldehyde solution and processed for histopathological examination and the second portion was used for DNA extraction.

Genomic DNA extraction of rats' livers and gel electrophoresis

DNA was extracted according to purification protocol of total DNA from animal tissues by using (SpinColumn Protocol) (QIAGEN, DNeasy, RNeasy, QIAGEN Group); DU (Beckman Instruments, Inc.). DNA concentrations of the studied rats were measured photometrically using DU 640 spectrophotometer at $260 \mathrm{~nm}$. Agarose gel was prepared according to Gothwal ${ }^{[23]}$. Molecular biology grade agarose was used to prepare $2 \%$ agarose gel in $1 \mathrm{X}$ Tris-acetateethylenediaminetetraacetic acid (TAE) buffer. The power supply was turned "on" at 100 volts for $45 \mathrm{~min}$ to allow separation of DNA marker bands. DNA marker (100-1200 b.p; Thermo-Scientific Generuler DNA ladder) was used in the agarose gel. 


\section{Histopathological examination}

One-half of each liver sample was fixed in $10 \%$ buffered neutral formalin solution. The fixed specimens were then trimmed, washed and dehydrated in ascending grades of alcohol. These specimens were cleared in xylene, embedded in paraffin, sectioned at 4 to 6 microns thickness and stained with hematoxylin and eosin ( $\mathrm{H}$ and $\mathrm{E})$. The microscopic examination of livers' tissue sections were carried out to evaluate the histopathological alterations according to Belal ${ }^{[24]}$ and the total pathological score of portal inflammation, necrosis, fibrosis-cirrhosis and steatosis was calculated for each sample by examining three randomly chosen fields of view per tissue section ${ }^{[25]}$.

\section{Statistical analysis}

Analysis of data was carried out using STATISTICA 7. Mann Whitney Wilcoxon test was used instead of unpaired t-test in non-parametric data (Standard deviation $(\mathrm{SD})>50 \%$ mean).

\section{Results}

Effect of red and yellow carrots water extracts on biochemical parameters:

Table (1) shows serum levels of liver profile of untreated control group and $\mathrm{CCl}_{4}$ treated control group throughout the whole study. The mean serum levels of AST, ALT, LDH and GGT of $\mathrm{CCl}_{4}$ treated control rats at the end of the $1^{\text {st }}, 2^{\text {nd }} 3^{\text {th }}, 4^{\text {th }}$ and $5^{\text {th }}$ weeks of the study were significantly increased compared to that of the untreated control rats (negative control), while the mean serum levels of $\mathrm{AChE}$ of $\mathrm{CCl}_{4}$ treated rats were significantly decreased at the end of the $2^{\text {nd }}, 3^{\text {th }}, 4^{\text {th }}$ and $5^{\text {th }}$ weeks, and non-significantly decreased at the end of $1^{\text {st }}$ week of the study compared to that of the untreated control rats.

Meanwhile, the mean serum levels of albumin in $\mathrm{CCl}_{4}$ treated control rats were non-significantly decreased at the end of all the studied weeks with only significant decrease at the end of the $3^{\text {th }}$ week compared to that of the untreated control rats. The mean serum levels of urea in $\mathrm{CCl}_{4}$ treated control rats at the end of the $2^{\text {nd }}, 4^{\text {th }}, 5^{\text {th }}$ weeks were significantly increased and insignificantly decreased at the end of the $1^{\text {st }}$ week and non-significantly increased at the end of the $3^{\text {th }}$ week of the study compared to that of the untreated control rats (negative control).

Table (2) shows that the mean serum levels of AST, ALT, LDH and GGT of red carrot protected rats were significantly decreased at the end of all weeks of the study compared to that of $\mathrm{CCl}_{4}$ treated rats by the end of the same corresponding studied weeks except at the end of the $1^{\text {st }}$ week, GGT serum levels of red carrot protected rats showed non-significant decrease compared to that of $\mathrm{CCl}_{4}$ treated rats by the end of the same corresponding studied week. The mean serum levels of AChE of red carrot protected rats showed a significant elevation at the

Table 1: Serum levels of liver profile in $\mathrm{CCl}_{4}$ treated \& untreated rats.

\begin{tabular}{|c|c|c|c|c|c|c|c|c|}
\hline \multicolumn{2}{|c|}{$\begin{array}{ll}\text { Paramaters } & \text { Groups } \\
\end{array}$} & $\begin{array}{l}\text { AST } \\
\text { U/L }\end{array}$ & $\begin{array}{l}\mathbf{A L T} \\
\mathbf{U} / \mathbf{L}\end{array}$ & $\begin{array}{l}\text { LDH } \\
\text { U/L }\end{array}$ & $\begin{array}{l}\text { GGT } \\
\text { U/L }\end{array}$ & $\begin{array}{l}\mathbf{A C h E} \\
\mathrm{U} / \mathrm{L}\end{array}$ & $\begin{array}{c}\text { Albumin } \\
\text { g/L }\end{array}$ & $\begin{array}{l}\text { Urea } \\
\text { mg/dl }\end{array}$ \\
\hline $\begin{array}{l}\text { (A1) Untreated } \\
\text { Control rats }\end{array}$ & Mean \pm S.D. & $155.8 \pm 57$ & $77.8 \pm 28$ & $622 \pm 228$ & $5.4 \pm 1.1$ & $503 \pm 153$ & $6.2 \pm 1.1$ & $48.4 \pm 3.2$ \\
\hline $\begin{array}{l}\left(\mathrm{B}_{1}-1\right) \quad \mathrm{CCl}_{4} \text { treated } \\
\text { rats by end of the } 1^{\text {st }} \\
\text { week. }\end{array}$ & $\begin{array}{c}\text { Mean } \pm \text { S.D } \\
P\end{array}$ & $\begin{array}{c}194 \pm 28 \\
<0.01\end{array}$ & $\begin{array}{l}97 \pm 14 \\
<0.05\end{array}$ & $\begin{array}{c}1556 \pm 228 \\
<0.01\end{array}$ & $\begin{array}{l}10 \pm 6 \\
<0.01\end{array}$ & $\begin{array}{l}400 \pm 255 \\
\text { N.S. }\end{array}$ & $\begin{array}{l}5 \pm 1.6 \\
\text { N.S. }\end{array}$ & $\begin{array}{l}47 \pm 5 \\
\text { N.S. }\end{array}$ \\
\hline $\begin{array}{l}\left(B_{1}-2\right) C C l_{4} \text { treated } \\
\text { rats by end of the } 2^{\text {nd }} \\
\text { week. }\end{array}$ & $\begin{array}{c}\text { Mean } \pm \text { S.D } \\
\text { P }\end{array}$ & $\begin{array}{c}418 \pm 90 \\
<0.01\end{array}$ & $\begin{array}{c}209 \pm 45 \\
<0.01\end{array}$ & $\begin{array}{c}3345 \pm 726 \\
<0.01\end{array}$ & $\begin{array}{l}15 \pm 4 \\
<0.01\end{array}$ & $\begin{array}{c}371 \pm 137 \\
<0.01\end{array}$ & $\begin{array}{l}5 \pm 1.3 \\
\text { N.S. }\end{array}$ & $\begin{array}{c}96.6 \pm 39 \\
<0.01\end{array}$ \\
\hline $\begin{array}{l}\left(\mathrm{B}_{1}-3\right) \mathrm{CCl}_{4} \text { treated } \\
\text { rats by end of the } 3^{\text {rd }} \\
\text { week. }\end{array}$ & $\begin{array}{c}\text { Mean } \pm \text { S.D } \\
\mathbf{P}\end{array}$ & $\begin{array}{c}568 \pm 90 \\
<0.01\end{array}$ & $\begin{array}{c}284 \pm 45 \\
<0.01\end{array}$ & $\begin{array}{c}4544 \pm 727 \\
<0.01\end{array}$ & $\begin{array}{l}15 \pm 6 \\
<0.01\end{array}$ & $\begin{array}{c}353 \pm 90 \\
<0.01\end{array}$ & $\begin{array}{c}3.6 \pm 1.3 \\
<0.01\end{array}$ & $\begin{array}{l}53 \pm 16 \\
\text { N.S. }\end{array}$ \\
\hline $\begin{array}{l}\left(\mathrm{B}_{1}-4\right) \mathrm{CCl}_{4} \text { treated } \\
\text { rats by end of the } 4^{\text {th }} \\
\text { week. }\end{array}$ & $\begin{array}{c}\text { Mean } \pm \text { S.D } \\
\text { P }\end{array}$ & $\begin{array}{c}527 \pm 109 \\
<0.01\end{array}$ & $\begin{array}{c}263 \pm 54 \\
<0.01\end{array}$ & $\begin{array}{c}4220 \pm 877 \\
<0.01\end{array}$ & $\begin{array}{l}14 \pm 8 \\
<0.01\end{array}$ & $\begin{array}{c}378 \pm 123 \\
<0.01\end{array}$ & $\begin{array}{l}5.4 \pm 1.3 \\
\text { N.S. }\end{array}$ & $\begin{array}{l}85 \pm 26 \\
<0.01\end{array}$ \\
\hline $\begin{array}{l}\left(\mathrm{B}_{1}-5\right) \mathrm{CCl}_{4} \text { treated } \\
\text { rats by end of the } \\
5^{\text {th }} \text { week. }\end{array}$ & $\begin{array}{c}\text { Mean } \pm \text { S.D } \\
\text { P }\end{array}$ & $\begin{array}{c}531 \pm 86 \\
<0.01\end{array}$ & $\begin{array}{c}265 \pm 43 \\
<0.01\end{array}$ & $\begin{array}{c}4251 \pm 689 \\
<0.01\end{array}$ & $\begin{array}{l}14 \pm 8 \\
<0.01\end{array}$ & $\begin{array}{c}301 \pm 89 \\
<0.01\end{array}$ & $\begin{array}{l}5.4 \pm 1 \\
\text { N.S. }\end{array}$ & $\begin{array}{l}57 \pm 21 \\
<0.05\end{array}$ \\
\hline
\end{tabular}

P: $\mathrm{CCl}_{4}$ treated group vs. negative control group.

$\mathrm{N} . \mathrm{S}=$ non- significant $(\mathrm{P}>0.05)$, significant $=(\mathrm{P}<0.05 \& \mathrm{P}<0.01)$. 
end of all the studied weeks compared to that of $\mathrm{CCl}_{4}$ treated rats by the end of the same corresponding studied weeks. The mean serum levels of albumin of red carrot protected rats showed a non-significant increase at the end of the $2^{\text {nd }}, 3^{\text {rd }}, 4^{\text {th }}$ and $5^{\text {th }}$ weeks, while non-significant decrease was observed at the end of the $1^{\text {st }}$ week compared to that of $\mathrm{CCl}_{4}$ treated rats by the end of the same corresponding studied weeks.
The mean serum levels of urea in red carrot protected rats were fluctuating between a non-significant increase at the end of the $1^{\text {st }}$ week and non-significant decrease at the end of the $4^{\text {th }}$ week while, significant elevation in the serum levels of urea in red carrot protected rats at the end of the $3^{\text {rd }}$ and $5^{\text {th }}$ weeks with significant decrease at the end of the $2^{\text {nd }}$ week were shown compared to that of $\mathrm{CCl}_{4}$ treated rats by the end of the same corresponding studied weeks.

Table 2: Serum levels of liver profile in red and yellow carrots extract protected rats.

\begin{tabular}{|c|c|c|c|c|c|c|c|c|}
\hline $\begin{array}{ll}\text { Groups } & \text { Param } \\
\end{array}$ & & $\begin{array}{l}\text { AST } \\
\mathbf{U} / \mathbf{L} \\
\end{array}$ & $\begin{array}{l}\mathbf{A L T} \\
\mathbf{U} / \mathbf{L} \\
\end{array}$ & $\begin{array}{c}\mathbf{L D H} \\
\mathbf{U} / \mathbf{L}\end{array}$ & $\begin{array}{l}\text { GGT } \\
\text { U/L }\end{array}$ & $\begin{array}{c}\mathbf{A C h E} \\
\mathbf{U} / \mathbf{L}\end{array}$ & $\begin{array}{c}\text { Albumin } \\
\text { g/dl }\end{array}$ & $\begin{array}{l}\text { Urea } \\
\text { mg/dl }\end{array}$ \\
\hline $\begin{array}{l}\left(\mathrm{B}_{1}-1\right) \mathrm{CCl}_{4} \text { treated rats by } \\
\text { end of the } 1^{\text {st }} \text { week. }\end{array}$ & Mean \pm S.D. & $194 \pm 28$ & $97 \pm 14$ & $1556 \pm 228$ & $10 \pm 6$ & $400 \pm 255$ & $5 \pm 1.6$ & $47 \pm 5$ \\
\hline $\begin{array}{l}\text { (B2-1) Red carrot protected } \\
\text { rats by end of the } 1^{\text {st }} \text { week. }\end{array}$ & $\begin{array}{c}\text { Mean } \pm \text { S.D. } \\
\text { P }\end{array}$ & $\begin{array}{l}131 \pm 22 \\
<0.05\end{array}$ & $\begin{array}{l}66 \pm 11 \\
<0.05\end{array}$ & $\begin{array}{l}1052 \pm 177 \\
<0.05\end{array}$ & $\begin{array}{l}8.4 \pm 2 \\
\text { N.S. }\end{array}$ & $\begin{array}{l}1524 \pm 375 \\
<0.01\end{array}$ & $\begin{array}{l}3.2 \pm 0.8 \\
\text { N.S. }\end{array}$ & $\begin{array}{l}62 \pm 24 \\
\text { N.S. }\end{array}$ \\
\hline $\begin{array}{l}\text { (B3-1) Yellow carrot } \\
\text { protected rats by end of the } \\
1^{\text {st }} \text { week. }\end{array}$ & $\begin{array}{c}\text { Mean } \pm \text { S.D. } \\
\text { P }\end{array}$ & $\begin{array}{l}148 \pm 21 \\
<0.05\end{array}$ & $\begin{array}{l}74 \pm 10 \\
\text { N.S. }\end{array}$ & $\begin{array}{l}1187 \pm 170 \\
\text { N.S. }\end{array}$ & $\begin{array}{l}6.4 \pm 2 \\
\text { N.S. }\end{array}$ & $\begin{array}{l}987 \pm 181 \\
<0.01\end{array}$ & $\begin{array}{l}4.4 \pm 0.6 \\
\text { N.S. }\end{array}$ & $\begin{array}{l}56 \pm 14 \\
\text { N.S. }\end{array}$ \\
\hline $\begin{array}{l}\left(\mathrm{B}_{1}-2\right) \mathrm{CCl}_{4} \text { treated rats by } \\
\text { end of the } 2^{\text {nd }} \text { week. }\end{array}$ & Mean \pm S.D. & $418 \pm 90$ & $209 \pm 45$ & $3345 \pm 726$ & $15 \pm 4$ & $371 \pm 137$ & $5 \pm 1.3$ & $96.6 \pm 39$ \\
\hline $\begin{array}{l}\text { (B2-2) Red carrot protected } \\
\text { rats by end of the } 2^{\text {nd }} \text { week. }\end{array}$ & $\begin{array}{c}\text { Mean } \pm \text { S.D. } \\
\text { P }\end{array}$ & $\begin{array}{c}213 \pm 27 \\
<0.01\end{array}$ & $\begin{array}{c}106 \pm 13 \\
<0.05\end{array}$ & $\begin{array}{l}1705 \pm 221 \\
<0.01\end{array}$ & $\begin{array}{l}6.2 \pm 3 \\
<0.01\end{array}$ & $\begin{array}{l}1610 \pm 601 \\
<0.01\end{array}$ & $\begin{array}{l}5.6 \pm 3 \\
\text { N.S. }\end{array}$ & $\begin{array}{l}60 \pm 9 \\
<0.05\end{array}$ \\
\hline $\begin{array}{l}\text { (B3-2) Yellow carrot } \\
\text { protected rats by end of the } \\
2^{\text {nd }} \text { week. }\end{array}$ & $\begin{array}{c}\text { Mean } \pm \text { S.D. } \\
\text { P }\end{array}$ & $\begin{array}{c}248 \pm 39 \\
<0.01\end{array}$ & $\begin{array}{c}124 \pm 19 \\
<0.05\end{array}$ & $\begin{array}{l}1990 \pm 318 \\
<0.01\end{array}$ & $\begin{array}{l}8.4 \pm 2 \\
<0.05\end{array}$ & $\begin{array}{c}1496 \pm 35 \\
<0.01\end{array}$ & $\begin{array}{l}4.6 \pm 1 \\
\text { N.S. }\end{array}$ & $\begin{array}{l}32 \pm 4 \\
<0.01\end{array}$ \\
\hline $\begin{array}{l}\left(\mathrm{B}_{1}-3\right) \mathrm{CCl}_{4} \text { treated rats by } \\
\text { end of the } 3^{\text {rd }} \text { week. }\end{array}$ & Mean \pm S.D. & $568 \pm 90$ & $284 \pm 45$ & $4544 \pm 727$ & $15 \pm 6$ & $353 \pm 90$ & $3.6 \pm 1.3$ & $53 \pm 16$ \\
\hline $\begin{array}{l}\text { (B2-3) Red carrot protected } \\
\text { rats by end of the } 3^{\text {rd }} \text { week. }\end{array}$ & $\begin{array}{c}\text { Mean } \pm \text { S.D. } \\
\text { P }\end{array}$ & $\begin{array}{c}222 \pm 30 \\
<0.01\end{array}$ & $\begin{array}{c}111 \pm 15 \\
<0.05\end{array}$ & $\begin{array}{l}1780 \pm 247 \\
\quad<0.01\end{array}$ & $\begin{array}{c}6.8 \pm 3.8 \\
<0.01\end{array}$ & $\begin{array}{l}1147 \pm 359 \\
<0.01\end{array}$ & $\begin{array}{l}4.4 \pm 1 \\
\text { N.S. }\end{array}$ & $\begin{array}{l}80 \pm 10 \\
<0.05\end{array}$ \\
\hline $\begin{array}{l}\text { (B3-3) Yellow carrot } \\
\text { protected rats by end of the } \\
3^{\text {rd }} \text { week. }\end{array}$ & $\begin{array}{c}\text { Mean } \pm \text { S.D. } \\
\text { P }\end{array}$ & $\begin{array}{c}295 \pm 54 \\
<0.01\end{array}$ & $\begin{array}{c}147 \pm 27 \\
<0.05\end{array}$ & $\begin{array}{l}2361 \pm 437 \\
<0.01\end{array}$ & $\begin{array}{l}6.2 \pm 3 \\
<0.01\end{array}$ & $\begin{array}{l}945 \pm 403 \\
<0.01\end{array}$ & $\begin{array}{l}4 \pm 1.6 \\
\text { N.S. }\end{array}$ & $\begin{array}{l}60 \pm 9 \\
\text { N.S. }\end{array}$ \\
\hline $\begin{array}{l}\left(\mathrm{B}_{1}-4\right) \mathrm{CCl}_{4} \text { treated rats by } \\
\text { end of the } 4^{\text {th }} \text { week. }\end{array}$ & Mean \pm S.D. & $527 \pm 109$ & $263 \pm 54$ & $4220 \pm 877$ & $14 \pm 8$ & $378 \pm 123$ & $5.4 \pm 1.3$ & $85 \pm 26$ \\
\hline $\begin{array}{l}\text { (B2-4) Red carrot protected } \\
\text { rats by end of the } 4^{\text {th }} \text { week. }\end{array}$ & $\begin{array}{c}\text { Mean } \pm \text { S.D. } \\
\text { P }\end{array}$ & $\begin{array}{c}272 \pm 31 \\
<0.01\end{array}$ & $\begin{array}{c}136 \pm 15 \\
<0.05\end{array}$ & $\begin{array}{l}2180 \pm 249 \\
\quad<0.05\end{array}$ & $\begin{array}{l}4 \pm 2 \\
<0.01\end{array}$ & $\begin{array}{c}1065 \pm 298 \\
<0.01\end{array}$ & $\begin{array}{l}6.2 \pm 0.5 \\
\text { N.S. }\end{array}$ & $\begin{array}{l}83 \pm 21 \\
\text { N.S. }\end{array}$ \\
\hline $\begin{array}{l}\text { (B3-4) Yellow carrot } \\
\text { protected rats by end of the } \\
4^{\text {th }} \text { week. }\end{array}$ & $\begin{array}{c}\text { Mean } \pm \text { S.D. } \\
\text { P }\end{array}$ & $\begin{array}{c}270 \pm 25 \\
<0.01\end{array}$ & $\begin{array}{c}135 \pm 12 \\
<0.05\end{array}$ & $\begin{array}{l}2164 \pm 205 \\
\quad<0.01\end{array}$ & $\begin{array}{l}4.8 \pm 4 \\
<0.01\end{array}$ & $\begin{array}{c}1001 \pm 34 \\
<0.01\end{array}$ & $\begin{array}{l}5.8 \pm 0.5 \\
\text { N.S. }\end{array}$ & $\begin{array}{l}76 \pm 14 \\
\text { N.S. }\end{array}$ \\
\hline $\begin{array}{l}\left(\mathrm{B}_{1}-5\right) \mathrm{CCl}_{4} \text { treated rats by } \\
\text { end of the } 5^{\text {th }} \text { week. }\end{array}$ & Mean \pm S.D. & $531 \pm 86$ & $265 \pm 43$ & $4251 \pm 689$ & $14 \pm 8$ & $301 \pm 89$ & $5.4 \pm 1$ & $57 \pm 21$ \\
\hline $\begin{array}{l}(B 2-5) \text { Red carrot protected } \\
\text { rats by end of the } 5^{\text {th }} \text { week. }\end{array}$ & $\begin{array}{c}\text { Mean } \pm \text { S.D. } \\
\text { P }\end{array}$ & $\begin{array}{c}278 \pm 56 \\
<0.01\end{array}$ & $\begin{array}{c}138 \pm 28 \\
<0.05\end{array}$ & $\begin{array}{l}2211 \pm 457 \\
\quad<0.05\end{array}$ & $\begin{array}{l}3 \pm 1.7 \\
<0.01\end{array}$ & $\begin{array}{c}1480 \pm 495 \\
<0.01\end{array}$ & $\begin{array}{l}6 \pm 0.0 \\
\text { N.S. }\end{array}$ & $\begin{array}{l}99 \pm 29 \\
<0.05\end{array}$ \\
\hline $\begin{array}{l}\text { (B3-5)Yellow carrot } \\
\text { protected rats by end of } \\
\text { the } 5^{\text {th }} \text { week. }\end{array}$ & $\begin{array}{c}\text { Mean } \pm \text { S.D. } \\
\text { P }\end{array}$ & $\begin{array}{c}283 \pm 51 \\
<0.01\end{array}$ & $\begin{array}{c}141 \pm 25 \\
<0.05\end{array}$ & $\begin{array}{l}2267 \pm 413 \\
<0.01\end{array}$ & $\begin{array}{l}3.6 \pm 3 \\
<0.01\end{array}$ & $\begin{array}{c}1240 \pm 32 \\
<0.01\end{array}$ & $\begin{array}{c}5.2 \pm 0.8 \\
\text { N.S. }\end{array}$ & $\begin{array}{c}116 \pm 41 \\
<0.01\end{array}$ \\
\hline
\end{tabular}

$\mathrm{P}$ : Red or yellow carrot protected groups vs. $\mathrm{CCl}_{4}$ treated group.

N.S = non- significant $(\mathrm{P}>0.05)$, significant $=(\mathrm{P}<0.05 \& \mathrm{P}<0.01)$. 
Table (2) shows the mean serum levels of AST, ALT, LDH and GGT of yellow carrot protected rats were significantly decreased at the end of all the studied weeks compared to that of $\mathrm{CCl}_{4}$ treated rats by the end of the same corresponding studied weeks except at the end of the $1^{\text {st }}$ week, ALT, LDH and GGT serum levels of yellow carrot protected rats showed insignificant decrease compared to that of $\mathrm{CCl}_{4}$ treated rats by the end of the same corresponding studied week. The mean serum levels of $\mathrm{AChE}$ of yellow carrot protected rats showed a significant elevation compared to that of $\mathrm{CCl}_{4}$ treated rats by end of the same corresponding studied weeks.

The mean serum levels of albumin of yellow carrot protected rats showed insignificant decrease at the end of the $1^{\text {st }}, 2^{\text {nd }}$, and $5^{\text {th }}$ weeks while showed insignificant increase at the end of the $3^{\text {rd }}$ and $4^{\text {th }}$ weeks compared to that of $\mathrm{CCl}_{4}$ treated rats by the end of the same corresponding studied weeks.

The mean serum levels of urea in yellow carrot protected rats were fluctuating between a significant decrease at the end of the $2^{\text {nd }}$ week and a significant increase at the end of the $5^{\text {th }}$ week while, nonsignificant elevation in the serum levels of urea in yellow carrot protected rats by the end of the $1^{\text {st }}$ and $3^{\text {rd }}$ weeks with non-significant decrease at the end of the $4^{\text {th }}$ week were shown compared to that of $\mathrm{CCl}_{4}$ treated rats by the end of the same corresponding studied weeks.

\section{DNA degradation analysis}

Table (3) shows that the genomic DNA levels of $\mathrm{CCl}_{4}$ treated rats at the end of the $2^{\text {nd }}$ and $4^{\text {th }}$ weeks were significantly decreased compared to the that of the untreated rats (-ve control). The genomic DNA levels of red and yellow carrots protected rats were insignificantly elevated at the end of the $2^{\text {nd }}$ week and significantly elevated at the end of the $4^{\text {th }}$ week of the study compared to that of the $\mathrm{CCl}_{4}$ treated rats (+ve control). Figure (1) demonstrates that the effect of supplementation of red and yellow carrots extracts on the genomic DNA integrity of different $\mathrm{CCl}_{4}$ treated rats' livers in addition of the genomic DNA integrity of untreated rat's liver (ve control) as well as the genomic DNA integrity of $\mathrm{CCl}_{4}$ treated rat liver (+ve control) where, Lane $\mathrm{M}$ : $1 \mathrm{~Kb} . \mathrm{p}$ DNA Ladder; Lane 1: Genomic DNA of untreated rat's liver (-ve control); Lane 2: Genomic DNA of $\mathrm{CCl}_{4}$ treated rat's liver (+ve control) 2 weeks post experimental running; Lane 3: Genomic DNA of $\mathrm{CCl}_{4}$ treated rat's liver (+ve control) 4 weeks post experimental running; Lane 4: Genomic DNA of yellow carrot extract protected rat's liver against $\mathrm{CCl}_{4}$ administration 2 weeks post experimental running; Lane 5: Genomic DNA of yellow carrot extract protected rat's liver against $\mathrm{CCl}_{4}$ administration 4 weeks post experimental running; Lane 6: Genomic DNA of red carrot extract protected rat's liver against $\mathrm{CCl}_{4}$ administration 2 weeks post experimental running; Lane 7: Genomic DNA of red carrot extract protected rat's liver against $\mathrm{CCl}_{4}$ administration 4 weeks post experimental running.

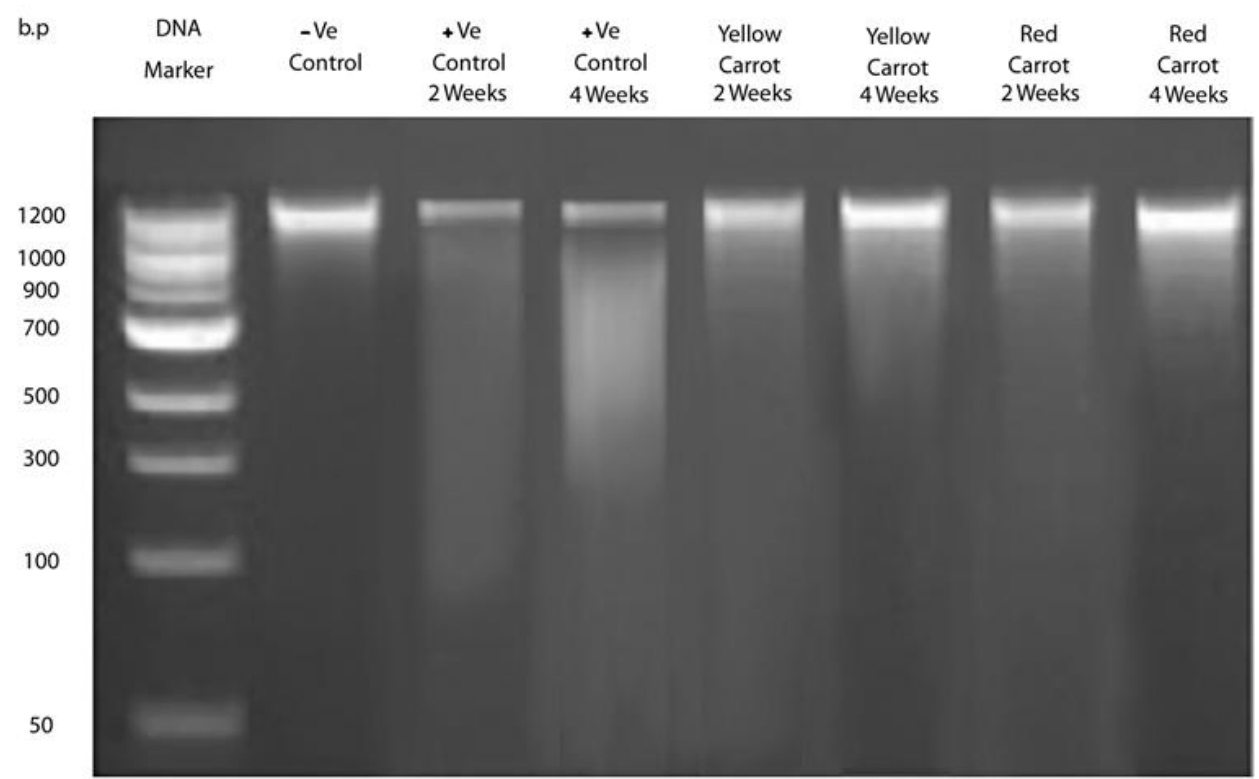

Fig. 1: Effect of supplementation of red and yellow carrots extracts on the DNA integrity of different $\mathrm{CCl}_{4}$ treated rats' livers and untreated rats' livers. Lane M: 1Kb.p DNA Ladder; Lane 1: Genomic DNA of untreated rat's liver (-ve control); Lane 2: Genomic DNA of $\mathrm{CCl}_{4}$ treated rat's liver (+ve control) 2 weeks post experimental running; Lane 3: Genomic DNA of $\mathrm{CCl}_{4}$ treated rat's liver (+ve control) 4 weeks post experimental running; Lane 4: Genomic DNA of yellow carrot protected rat's liver against $\mathrm{CCl}_{4}$ administration 2 weeks post experimental running; Lane 5: Genomic DNA of yellow carrot protected rat's liver against $\mathrm{CCl}_{4}$ administration 4 weeks post experimental running; Lane 6: Genomic DNA of red carrot protected rat's liver against $\mathrm{CCl}_{4}$ administration 2 weeks post experimental running; Lane 7: Genomic DNA of red carrot protected rat's liver against $\mathrm{CCl}_{4}$ administration 4 weeks post experimental running. 
Table 3: DNA levels of all studied groups (ng/g tissue).

\begin{tabular}{|c|c|c|}
\hline $\begin{array}{ll}\text { Groups } & \text { Weeks } \\
\end{array}$ & $2^{\text {nd }}$ Week & $4^{\text {th }}$ Week \\
\hline $\begin{array}{c}\text { Group A (Negative Control) } \\
\text { Mean } \pm \text { S.D. }\end{array}$ & $2150 \pm 160$ & $2150 \pm 160$ \\
\hline $\begin{array}{c}\mathbf{C C l}_{\mathbf{4}} \text { treated (Positive Control) } \\
\text { Mean } \pm \text { S.D. } \\
* \mathrm{P}\end{array}$ & $\begin{array}{c}619 \pm 35 \\
<0.01\end{array}$ & $\begin{array}{c}280 \pm 30 \\
<0.01\end{array}$ \\
\hline $\begin{array}{c}\text { Red carrot protected rats } \\
\text { Mean } \pm \text { S.D. } \\
* * \mathrm{P}\end{array}$ & $\begin{array}{c}688 \pm 40 \\
\text { N.S. }\end{array}$ & $\begin{array}{c}793 \pm 25 \\
<0.01\end{array}$ \\
\hline $\begin{array}{c}\text { Yellow carrot protected rats } \\
\text { Mean } \pm \text { S.D. } \\
* * \mathrm{P}\end{array}$ & $\begin{array}{c}679 \pm 529 \\
\text { N.S. }\end{array}$ & $\begin{array}{c}576 \pm 30 \\
<0.01\end{array}$ \\
\hline
\end{tabular}

*P: $\mathrm{CCl}_{4}$ treated group vs. negative control group.

**P: Red or yellow carrot protected group vs. $\mathrm{CCl}_{4}$ treated group.

N.S = non- significant $(\mathrm{P}>0.05)$, significant $=(\mathrm{P}<0.01)$.
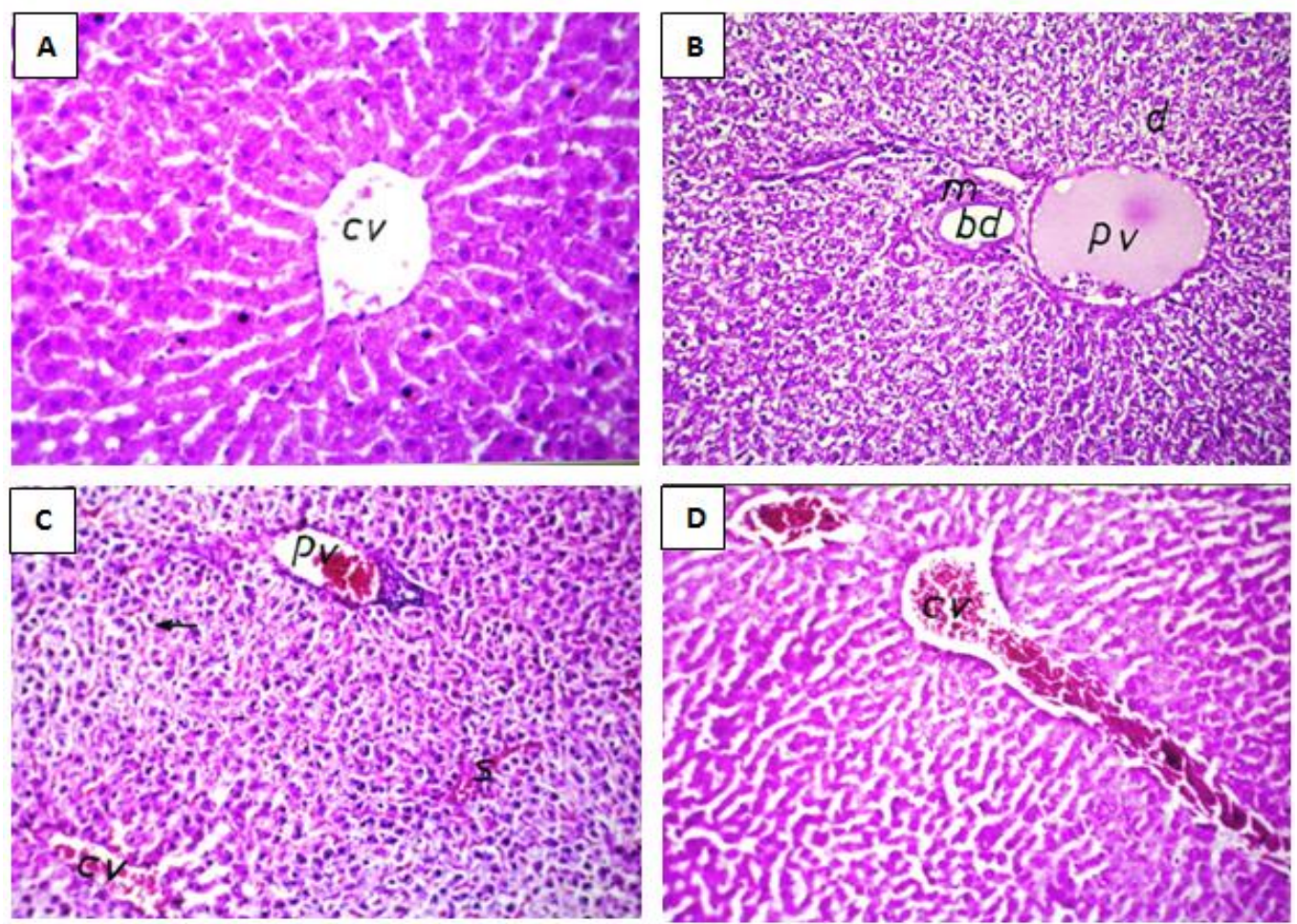

Fig. 2: Effect of yellow and red carrots on histopathological changes in presence or absence of $\mathrm{CCl}_{4}$ induced liver toxicity. $\mathrm{A}$; normal control group, $\mathrm{B} ; \mathrm{CCl}_{4}$ group, $\mathrm{C}$; yellow carrot $+\mathrm{CCl}_{4}$ group; $\mathrm{D}$; red carrot $+\mathrm{CCl}_{4}$ group, cv; central vein, pv; portal vein, d; degenerated hepatocytes, bd; bile ducts, m; inflammatory cells.(H\&E x 40).

\section{Histopathological examinations}

The biochemical findings of the present study were supported with histopathological examination of rats' livers sections. The histopathological examination results of the livers of the normal rats fed on standard diet (-ve control) clearly showed normal histological picture (figure-2A). Injured liver with $\mathrm{CCl}_{4}$ administration showed portal loss of hepatic lobular architecture. Ballooning of hepatocytes, deformed cord arrangement and disturbed sinusoids were observed. The hepatocytes showed marked degree of hydropic, steatotic changes and massive necrosis. Portal tracts were extended as distinguished with marked numbers of chronic inflammatory cells and fibrous tissue. Fibrosis was markedly presented by $70 \%$ (figure-2B). Treatments of injured liver with red or yellow carrot showed significant signs of amelioration of $\mathrm{CCl}_{4}$ induced liver injury as evident from the presence of well-formed nucleated hepatocytes arranged in cord with obvious sinusoidal arrays. Minimal fat vacuoles and minimal inflammatory lymphocyte infiltrations were observed. Fibrosis reached to $10 \%$, and mild degrees of steatosis and hydropic changes were recorded (figures-2C\&2D). 


\section{Discussion}

Carbon tetrachloride $\left(\mathrm{CCl}_{4}\right)$ is a widely used industrial solvent and a xenobiotic that can induce free radicals mediated hepatitis in humans as well as animals. Many researchers have utilized $\mathrm{CCl}_{4}$ to induce liver injury in experimental animals through generation of free radicals by its reductive metabolism via hepatic cytochrome P450s. This will cause lipid peroxidation of cellular and organelle membranes as a primary pathogenic step ${ }^{[26,27]}$. In the present study, subcutaneous injection with $\mathrm{CCl}_{4}$ of the studied rats twice a week led to significant elevation in the serum levels of AST, ALT, LDH and GGT by the end of all the studied weeks as well as significant decrease in the serum level of AChE by the end of the $2^{\text {nd }}, 3^{\text {rd }}, 4^{\text {th }}$ and $5^{\text {th }}$ weeks compared to that of the untreated control rats indicating considerable hepatocellular injury. The present results agreed with that of Teocharis et al. ${ }^{[28]}$, who reported that $\mathrm{CCl}_{4}$ treatment causes an increase in serum levels of ALT, AST and $\mathrm{LDH}$ compared to $\mathrm{CCl}_{4}$ untreated rats. Also Schmidt et al. ${ }^{[29]}$ stated that a damage to the structural integrity of the liver which has been induced by $\mathrm{CCl}_{4}$ mirrors an increase in the activities of serum transaminases, as these are located in the cytoplasm and released into the circulation after cellular damage. The decrease in AChE activity could be due to the decrease of the enzyme synthesis by the inhibitory nature of toxicant in liver ${ }^{[30]}$.

Supplementation of red and yellow carrot water extracts to the rats of the injured group in the present study attenuated the elevated enzyme activities and lowered the serum levels of $\mathrm{AChE}$ induced by $\mathrm{CCl}_{4}$ in a time dependent manner with subsequent improvement and recovery towards normalization of these enzymes. These results suggest that the two carrot extracts prevent the leakage of intracellular enzymes by its membrane stabilizing activity through accelerated regeneration of hepatocyte parenchymal cells, thus protecting the hepatocytes against membrane fragility ${ }^{[31]}$.

In the present study, there was non-significant decline in the serum levels of albumin in the $\mathrm{CCl}_{4}$ treated control rats by the end of all weeks of the present study except at the end of the $3^{\text {rd }}$ week, the decrease in the serum albumin was significant compared to the untreated rats and this fluctuation could be due to interaction of $\cdot \mathrm{CCl}_{3}$ with protein molecules leading to an impairment of cellular processes ${ }^{[32]}$. The mean serum values of urea in $\mathrm{CCl}_{4}$ treated control rats were fluctuating between significant elevations at the end of the $2^{\text {nd }}, 4^{\text {th }}, 5^{\text {th }}$ weeks and non-significant elevation at the end of the $3^{\text {th }}$ week compared to that of the untreated control rats (negative control), which agree with the previous study of Bishayee et al. ${ }^{[31]}$ that the serum levels of urea in $\mathrm{CCl}_{4}$ treated mices were significantly elevated compared to untreated control mices (-ve control). Urea was used as indicator of renal function, elevated blood urea is known to be linked with an increased protein catabolism to urea as a result of increased synthesis of arginase enzyme involved in urea production ${ }^{[33]}$.
Treatment with the two carrots extracts significantly reversed these changes. The probable mechanism by which the carrots extracts exert their hepatoprotective action against $\mathrm{CCl}_{4}$-induced hepatocellular metabolic alterations could be due to the stimulation of hepatic regeneration via an improved synthesis of protein, or interference with the microsomal activation of $\mathrm{CCl}_{4}$ and/or its accelerated detoxification and excretion. Carotenes in the carrot extract include $\beta$-carotene, $\alpha$ carotene, $\gamma$ - carotene, lycopene, cryptoxanthin, leutein, many partly degraded carotenoids such as abscisic acid, trisporic acid, $\beta$-apo- carotenals, crocetin and many common polar carotenoids e.g violaxanthin ${ }^{[34,35]}$. Some of the above compounds have the potential to minimize the deleterious effects of free radicals including the peroxy radicals ${ }^{[36]}$.

The present results revealed that the genomic DNA of $\mathrm{CCl}_{4}$ treated group (+ve control) two weeks and four weeks post experimental running (Fig. 1, lane 2\& 3) shows a massive degradation reached almost to maximum at the end of the $4^{\text {th }}$ week of the study compared to that of the untreated (-ve control) group. This finding came in agreement with that of Chung et al. ${ }^{[32]}$ who reported that the isozymes of liver microsomal cytochrome $\mathrm{P} 450$ within the endoplasmic reticulum metabolize carbon tetrachloride molecules to trichloromethyl radicals $\left(\cdot \mathrm{CCl}_{3}\right)$. These free radicals can interact with DNA, proteins, nucleic acids, fatty acids and lipids causing impairment of cellular processes such as lipid metabolism. Also, these results matched with that of Al Malki et al. ${ }^{[15]}$; Al Malki and Abo- Golayel ${ }^{[37]}$ who showed that the genomic DNA of $\mathrm{CCl}_{4}$ treated group (+ve control) at the end of the $2^{\text {nd }}$ week of the experiment exhibited a massive degradation compared to that of the untreated (-ve control) group.

The protective role of red and yellow carrots extracts has also been reflected on the integrity of the genomic DNA of the red and yellow carrots protected rats. Lanes 4-7 of agarose gel electrophoresis reflects gradual repair and improvement of the genomic DNA integrity of red and yellow carrots protected rats two weeks and four weeks post experimental running which was non-significant at the end of the $2^{\text {nd }}$ week of the experiment and became significant improvement by the end of the $4^{\text {th }}$ week of the experiment; this could be due a cumulative or time dependent protective effect of red and yellow carrots water extracts on molecular level against $\mathrm{CCl}_{4}$ hepatocellular damage. This is an indication that red and yellow carrots water extracts were efficient enough to restore the proper functions of hepatocytes. The enhanced recovery of the genomic DNAs following red and yellow carrot water extracts administration mirrors results that we have obtained on the gel. This indicates that the hepatic protection of red and yellow carrot water extracts on the molecular level was effective and stronger by the end of the $4^{\text {th }}$ week of the study (figure 1 , lanes $5 \& 7$ ), while at the end of both the $2^{\text {nd }}$ week of the study (figure 1, lanes $4 \& 6$ ), the hepatic protection was not efficient enough and this may be due to excessive 
oxidative damage caused by $\mathrm{CCl}_{4}$ in the absence of proper DNA repair ${ }^{[38]}$.

The results of the present study agreed with that of Siân et al. ${ }^{[39]}$ who reported that carotenoids induce stimulation of DNA SSB repair, while, other researchers have suggested that such an effect could be due to enhanced protection of the DNA from ongoing damage over the course of the experiment (i.e. a direct antioxidant protection provided by the carotenoid within the cells ${ }^{[40,41]}$. Based on the DNA findings, it is clear that the hepatoprotectivity of red carrot extract was better than that with yellow carrot extract against $\mathrm{CCl}_{4}$ hepatotoxicity since, the DNA levels as well as the integrity on the gel of red carrot protected rats were significantly better than that in yellow carrot protected rats at the end of the $4^{\text {th }}$ week of the study.

The histopathological study is direct evidence of efficacy of carrot as protectant. The histopathological findings of the present study in $\mathrm{CCl}_{4}$ treated rats came in agreement with previous studies ${ }^{[4,42,43]}$ which reported that $\mathrm{CCl}_{4}$ administration to experimental rats led to hepatic damage which due to the formation of free radicals during the metabolism of $\mathrm{CCl}_{4}$, targeting the microsomal lipids and proteins resulting in hepatic necrosis as a consequence of lipid peroxidation. Treatments of injured liver with red or yellow carrot reversed most of the histopathological alterations induced by $\mathrm{CCl}_{4}$ All the histological changes observed were in correlation with the biochemical and molecular parameters of the liver.

Conclusion: It is concluded that administration of red or yellow carrots extracts decrease the $\mathrm{CCl}_{4}$-induced elevation in biochemical and molecular parameters. These findings suggest that the two carrots were effective in bringing about functional improvement of hepatocytes. The healing effect of these carrots was also confirmed by histological observations. Our results demonstrated that the possible hepatoprotective mechanisms of the carrot on $\mathrm{CCl}_{4}$-induced liver damage in rats might be due to the following effects: (1) inhibiting the cytochrome P450-dependent oxygenase activity; (2) preventing lipid peroxidation; and (3) stabilizing the hepatocyte membrane. The active compounds of red and yellow carrots which are responsible for the observed hepatoprotective and antioxidant effects, have not been isolated in this study. Therefore, further studies should be conducted to determine the active compounds that are responsible for the hepatoprotective effects and the mechanisms of action involved in the hepatoprotective effect.

\section{Acknowledgement}

The authors are thankful to the appreciated help that has been introduced by the Medical Research Center administration and animal house, Faculty of Medicine, Ain Shams University in which this work has been achieved.

\section{References}

1) Kashaw, V., Amit, K. N., and Abhinav, A. (2011).
Hepatoprotective Prospective Of Herbal Drugs and Their Vesicular Carriers-A Review. International Journal of Research in Pharmaceutical and Biomedical Sciences. 2 (2): 360-374.

2) Handa, S.S. (1991). Plants as drugs. The Eastern Pharmacist. 34:79-85.

3) Kanter, M., Coskun, O., and Budancamanak, M. (2005). Hepatoprotective effects of Nigella sativa L and Urtica dioica $L$ on lipid peroxidation, antioxidant enzyme systems and liver enzymes in carbon tetrachloride-treated rats. World Journal of Gastroenterology. 11(42): 6684- 6688.

4) Weber, L.W., Boll, M., and Stampfl, A. (2003). Hepatotoxicity and mechanism of action of haloalkanes: carbon tetrachloride as a toxicological model. Crit. Rev. Toxicol. 33: 105-136.

5) Thrall, K. D., Vucelick, M. E., Gies, R. A., Zangar, R. C., Weitz, K. K., Poet, T. S., Springer, D. L., Grant, D. M. and Benson, J. M. (2000). Comparative metabolism of carbon tetrachloride in rats, mice, and hamsters using gas uptake and PBPK modeling. J. Toxicol. Environ. Health A. 60: 531548.

6) Dhiman, A., Nanda, A., and Ahmad, S. (2012). A recent update in research on the antihepatotoxic potential of medicinal plants. Journal of Chinese Integrative Medicine.10 (2):117-127.

7) Vasudevan, M., Gunnam, K.K., and Parle, M. (2006). Antinociceptive and anti-inflammatory properties of Daucus carota seeds extract. Journal of Health Science. 52(5): 598-606.

8) Yu, L.L., Zhou, K.K., and Parry, J. (2005). Antioxidant properties of cold pressed black caraway, carrot, cranberry, and hemp seed oils. Food Chem, 91(4): 723-729.

9) Sesso, H.D. (2006). Carotenoids and cardiovascular disease: what research gaps remain? Curr. Opin. Lipidol. 17(1): 11-16.

10) Zhang, D., and Hamauzu, Y. (2004). Phenolic compounds and their antioxidant properties in different tissues of carrots. J Food Agric Environ. 2: 95-100.

11) Ylonen, K., Alfthan, G., and Groop, L. (2003). Dietary intake and plasma concentrations of carotenoids and tocopherols in relation to glucose metabolism in subjects at a high risk of type 2 diabetes. Am J Clin Nutri. 73: 424-414.

12) Kobaek-Larsen, M., Christensen, L.P., Vach, W., Ritskes-hoitinga, J., and Brandt, K. (2005). Inhibitory effects of feeding carrots of falcarinol on development of azoxymethane-induced preneoplastic lesions in the rat colon. J Agric Food Chem. 53:18231827.

13) Nicolle, C., Gueux, E., Lab, C., Jaffrelo, L., Rock, E., Mazur, A., Amouroux, P., and Remesy, C. (2004). Lyophilized carrot ingestion lowers lipemia and beneficially affects cholesterol metabolism in cholesterol- fed C57BL/6J mice. Europ. J. Nutr. 43: 237-245. 
14) Dawit, D., Eyassu, M., Asfaw, D., Dawit, A., Kelbessa, U., Wallelign, M., Daniel, M., Ashenafi, A., and Yared, M. (2006). In vivo antimalarial activityof hydroalcoholic extracts from Asparagus africanus Lam. inmice infected with Plasmodium berghei. Ethiop. J. Health Dev. 20(2):112-118.

15) Al-Malki A. L., Abo-Golayel, M. K., Abo-Elnaga, G., and Al-Beshri, H. (2013). Hepatoprotective effect of dandelion (Taraxacum officinale) against induced chronic liver cirrhosis. Journal of Medicinal Plants Research. 7(20):1494-1505.

16) Zhao, D.C., Lei JX, Rui Chen, Yu WH, Zhang ZM, Li SN, and Xiang P. (2005). Bone marrowderived mesenchymal stem cells protect against experimental liver fibrosis in rats. World $\mathbf{J}$ Gastroenterol. 11(22):3431-3440.

17) Henry, R.J., Cannon, D.C., and Winkleman, J.W. (1974). Clinical chemistry: Principles and techniques. Harper and Row, NewYork.

18) Gerhar, S., Roberto, B., Ferruccio, C., Georges, F., and Carlo, A.F. (2002). IFCC Primary Reference Procedures for the Measurement of Catalytic Activity Concentrations of Enzymes at $37^{\circ} \mathrm{C}$. International Federation of Clinical Chemistry and Laboratory Medicine (IFCC), Part 6. Reference Procedure for the Measurement of Catalytic Concentration of Glutamyltransferase. Clin Chem Lab Med. 40(7):734-738.

19) Elias, A., Theodore, S.Z., and Warren, E.C. (1963). Urinary Alkaline Phosphatase ActivityI. Elevated Urinary LDH and Alkaline Phosphatase Activities for the Diagnosis of Renal Adenocarcinomas. JAMA. 185(10):769-775.

20) Mansfield, D.H., Webb, G., Clark, D.G. and Taylor, I.E. (1978). Partial Purification and Some Properties of a Cholinesterase from Bush Bean (Phaseolus vulgaris L.) Roots. Biochem. J. 175: 769-777.

21) Chaney, A.L., and Marbach, E.P. (1962). Modified reagents for determination of urea and ammonia. Journal of Clinical Chemistry. 8:130.

22) Pinnell, A.E., and Northam, B.E. (1978). New automated dyebinding method for serum albumin determination with bromocresol purple. Clin Chem. 24: 80.

23) Gothwal, R.J., Nigam, V.K., Mohan, M.K., Sasmal, D., Ghosh, P. (2007). Extraction of bulk DNA from Thar Desert soils for optimization of PCR-DGGE based microbial community analysis. Environmental Biotechnology. 10(3):400-408.

24) Belal, N.M. (2011). Hepatoprotective Effect of Feeding Celery Leaves Mixed with Chicory Leaves and Barley Grains to Hypercholesterolemic Rats. Asian Journal of Clinical Nutrition 3(1): 14-24.

25) Ishak, K., Baptista, A., Bianchi, L., Callea, F., De Groote, J., Gudat, F., Denk, H., Desmet, V., Korb, G., MacSween, R.N. (1995). Histological grading and staging of chronic hepatitis. J Hepatology. 22: 696- 699.
26) Parola, M., Leonarduzzi, G., Biasi, F., Albano, M., Biocca, E., Poli, G., Dianzani, U. (1992). Vitamin E dietary supplementation protects against $\mathrm{CCl}_{4^{-}}$ induced chronic liver damage and cirrhosis. Hepatology. 16: 1014-1021.

27) Ming, Y. H., Timothy, Y.C.F., Ping-Hsiao, S., Chia-Pu, L., and Gow-Chin, Y. (2006). Du-Zhong (Eucommia ulmoides Oliv.) leaves inhibit $\mathrm{CCl}_{4}$ induced hepatic mortility in the elderly. Ann Epidmiol. 5: 255-282.

28) Teocharis, S.E., Margelo, A.P., Skaltsas, S.D., Spiliopoulou, C.A., and Koutselinis, A.S. (2001). Induction of metallothionein in the liver of carbon tetrachloride intoxicated rats: an immunohistochemical study. Toxicology 161:129138.

29) Schmidt, E., Schmidt, F.W., Mohr, J., Otto, P., Vido, T., Wrogeman, K., and Herfarth, C. (1975). Liver morphology and enzyme release further studies in the isolated perfused rat liver. In: Keppler, D. (Ed.), Pathogenesis and Mechanism of Liver Cell Necrosis. Medical and Technical Publications, Lancester, pp. 147.

30) Sallie, R., Tredger, J.M., and William, R. (1991). Drugs and the liver biopharmaceutical drug disposition. 12:251-259.

31) Bishayee, A., Sarkar, A. and Chatterjee, M. (1995). Hepatoprotective activity of carrot (Daucus carota L.) against carbon tetrachloride intoxication in mouse liver. J. Ethnopharmacology, 47: 69-74.

32) Chung, M.P., Yeon, S.C., Hyun, J.Y., Chung, W.C., and Young, S.S. (2010). Amelioration of oxidative stress by dandelion extract through CYP2E1 suppression against acute liver injury induced by carbon tetrachloride in sprague-dawley rats. Phytother. Res., 24(9):1347-1353.

33) Yanardag, R. and Sacan, O.O. (2007). Combined effects of vitamin C, vitamin E, and sodium selenate supplementation on absolute ethanol-induced injury in various organs of rats. Int J Toxicol., 26:513-523.

34) Straub, O. (1987). In: F. Pfander (Ed.), Key to Carotenoids, $2^{\text {nd }}$ Edn., Birkhauser Verlag, Basel, pp. 296.

35) Olson, J.A. (1989). Provitamin A function of carotenoids: the conversion of B-carotene into vitamin A. Journal of Nutrition. 119: 105-108.

36) Burton, G.W. (1989). Antioxidant action of carotenoids. Journal of Nutrition. 119: 109- 111.

37) Al-Malki A. L., and Abo-Golayel M. K. (2013). Hepatoprotective Efficacy of Chicory alone or combined with Dandelion leaves against induced Liver Damage. Life Science Journal. 10(4): 140-157.

38) Van Loon, A.A., Sonneveld, E., Hoogerbrugge, J., Vander Schans, G.P., Grootegoed, J.A., Lohman, P.H.M., and Baan, R.A. (1993). Induction and repair of single strand breaks and DNA base damage at different cellular stages of spermatogenesis of the hamster upon in vitro exposure to ionizing radiation. Mutat. Res. 294:139-148. 
39) Asthley, S.B., Elliott, R.M., Archer, D.A. and Southon, S. (2004). Evidence that dietary supplementation with carotenoids and carotenoid rich foods modulates the DNA damage: Repair balance in human lymphocytes. British Journal of Nutrition. 91: 63-72.

40) Fillion, L., Collins, A., and Southon, S. (1998). Beta-carotene enhances the recovery of lymphocytes from oxidative DNA damage. Acta Biochim Pol 45: 183-190.

41) Torbergsen, A.C., and Collins, A.R. (2000). Recovery of human lymphocytes from oxidative DNA damage; the apparent enhancement of DNA repair by carotenoids is probably simply an antioxidant effect. Eur J Nutr. 39: 80-85.

42) Parola, M., Leonarduzzi, G., Biasi, F., Albano, E., Biocca, M.E., Poli, G., and Dianzani, M.U. (1992). Vitamin E dietary supplementation protects against carbon tetrachloride induced chronic liver damage and cirrhosis. Hepatology. 16(4): 1014-1021.

43) Ozturk, M., Akdogan, M., Keskin, I., Kisioglu, A.N., Oztas S., and Yildiz, K. (2012). Effect of Silybum marianum on acute hepatic damage caused by carbon tetrachloride in rats. Biomedical Research. 23 (2): 268-274. 